\title{
Ultrastructural Changes and Shear Force of Duck Meat during Aging at $0^{\circ} \mathrm{C}$
}

\author{
Young Boong Kim*, Ki Hong Jeon, Young Ho Kim, Nam Hyuck Lee, Su Kyung Ku, and Aera Jang ${ }^{1}$ \\ Korea Food Research Institute, Sungnam 463-746, Korea \\ ${ }^{1}$ Department of Animal Products and Food Science, Kangwon National University, Chuncheon 200-701, Korea
}

\begin{abstract}
The purpose of this study was to evaluate the ultrastructural and shear force changes of duck breast and leg meat during aging at $0^{\circ} \mathrm{C}$. Pekin ducks ( $45 \mathrm{~d}$ old) purchased from Greemud Co. were used for this experiment, and were stored at $0^{\circ} \mathrm{C}$ for $7 \mathrm{~d}$ in order to determine the changes of the meat structure using transmission electron microscopy (TEM) and shear force. At day 0, A-band, I-band, M-line and Z-line of sarcomeres were seen clearly, but sarcomeres started to lose structure and become extended in length from day 2 . With extended aging periods, myofibrils were destroyed and symptoms of aging became more obvious. In the duck breast meat, some myofibrils were also destroyed at the Z-line, but were mainly destroyed at the M-line. The change in structure of duck leg meat over time was similar to that of breast meat. After five days and seven days of aging, mitochondria size and quantity were determined to be increased between the myofibrils. Shear force was decreased over time. From this study, aging at $0^{\circ} \mathrm{C}$ was found to negatively influence the ultrastructure and shear force of duck meat.
\end{abstract}

Key words: aging, duck, ultrastructure, sarcomere, shear force

\section{Introduction}

Of all the various characteristics of meat quality, tenderness is considered to be the most important factor for the consumer (Gerelt et al., 2001). Since it is generally believed that aging improves meat tenderness, and that appropriate aging is very important to increase meat quality. The tenderness of meat after rigor mortis is affected to a great degree by changes of myofibrils. The weakening of the myofibrillar structure, with the consequent transversal fragmentation of sarcomeres, is a major structure change in myofibrils during aging (Mestre et al., 2002). In postmortem muscle, disintegration of the Z-line is one of the major structural changes. Suzuki et al. (1982) reported that the disintegration of meat could be related to the removal of the Z-line. The changes in muscle fiber size and percentage may affect not only the muscle characteristics, but overall quality and appearance as well (Barowicz, 2006).

*Corresponding author: Young Boong Kim, Processing Technology Research Group, Convergence Technology Research Division, Korea Food Research Institute, Sungnam 463-746, Korea. Tel: 82-31-780-9180, Fax: 82-31-780-9076, E-mail: kybaaa@kfri. re.kr
Current evidence indicates that postmortem meat tenderization is primarily the result of calpain mediated degradation of key myofibrillar proteins and the cytoskeleton (Goll et al., 1983; Goll et al., 1992; Koohmaraie, 1995, Koohmaraie, 1996; Ouali, 1992). Most of the cytoskeletal proteins, such as desmin, vinculin, filamin, and dystrophin, as well as the sarcomere proteins titin and nebulin, are native substrates of m-calpain, and the degradation of vinculin and desmin has been shown to correlate with postmortem meat tenderization (Koohmaraie et al., 1995; Taylor et al., 1995).

Among all poultry meats, chicken meat is the most widely used in various cuisines and food products, and consumption of duck meat is relatively very low. Duck is also poultry, like chicken, but it has red muscle in the breast. Hence, it is believed that duck breast meat may have different characteristics in its ultrastructure to that of chicken meat. Many researchers have reported the ultrastructural changes of beef (Boyer and Greaser, 1998; Maher et al., 2005), chicken (Ahn and Park, 1998; Yoon, 2003), rabbit (Sotelo et al., 2004; Mestre Prates et al., 2002), reindeer (Taylor et al., 2002) and cattle and sheep (Illian et al., 2004) but little study has regarded the ultrastructural changes of duck meat during aging. Therefore, 
the purpose of this study was to evaluate the ultrastructural and shear force changes of duck breast and leg meat during storage at $0^{\circ} \mathrm{C}$ for $7 \mathrm{~d}$.

\section{Materials and Methods}

\section{Sample preparation}

$45 \mathrm{~d}$ old pekin ducks from Greemud Co. were used for this experiment. Thirty-five duck carcasses were obained from a slaughter house (Moran Food Co., located in Chungbook province, Korea) and that were separated into breast and leg lean meat and stored separately for $7 \mathrm{~d}$ in a refrigerator at $0^{\circ} \mathrm{C}$ in vacuum packing.

\section{Transmission electron microscopy analysis (TEM)}

The ultrastructural changes in duck breast and leg meat during storage were evaluated using TEM. The samples of duck meat were cut $(1 \times 3 \times 5 \mathrm{~mm})$, fixed with $5 \%$ glutaldehyde and cut again into cubes $(1 \times 1 \times 1 \mathrm{~mm})$. Secondary fixation was done with $1 \%$ osmium tetroxide and samples were then kept for $90 \mathrm{~min}$ at $4^{\circ} \mathrm{C}$. After samples were dehydrated with ethanol and propylene oxide, they were dipped in epon mixture and propylene oxide $(1: 1)$ overnight. Samples were then buried under epoxy resin embedding media and were polymerized for hardening sample tissues at $35,45,60$ and $70^{\circ} \mathrm{C}$, respectively. These samples were cut into ultrathin microtome longitudinal sections (60-70 nm) and were stained with uranyl acetate and lead citrate. TEM (Carl Zeiss LEO912AB, German) was used for this experiment.

\section{Shear force}

Sample was cooked individually in polyethylene bags immersed in a water bath for $1 \mathrm{~h}$ at $80^{\circ} \mathrm{C}$. After cooking, the samples were cooled to room temperature for $30 \mathrm{~min}$. A sample was cut perpendicular to the muscular fiber $(1.0 \times 3.0 \times 1.0 \mathrm{~cm})$ and the shear force values were determined with a Texture analyzer (TA-XT 2 stable micro system, UK). The conditions for shear force analysis were set as: knife probe (force, $100 \mathrm{~g}$ ), test speed (2.0 $\mathrm{mm} / \mathrm{s})$, post test speed $(10.0 \mathrm{~mm} / \mathrm{s})$, and rupture test distance $(10.0 \mathrm{~mm} / \mathrm{s})$

\section{Statistical analysis}

All statistical analyses were performed using the General Linear Model (GLM) procedure in the SAS software (SAS, 2002). A software program using Duncan's multiple range tests to compare treatment means was applied, and the statistical significance was indicated at $p<0.05$.
All tests were carried out in triplicate, and were expressed as mean $\pm \mathrm{SD}$.

\section{Results and Discussion}

\section{Transmission electron microscopy analysis (TEM)}

After the slaughtering of ducks, the muscle stiffens due to rigor mortis, but after some hours, aging starts, and the muscle structure becomes softer due to various chemical reactions. During this change, storage temperature is believed to be one of the most important factors determining the quality of meat (Bendall, 1975; Lee et al., 1979).

The proteins that are degraded during myofiber degradation are myofibrillar and cytoskeletal proteins, which include troponin-I, troponin-T, desmin, vinculin, metavinculin, dystrophin, nebulin, and titin (Robson et al., 1997; Taylor et al., 1995). Three major cytoskeletal structures are degraded when meat is tender: Z-line to Z-line attachments by intermediate filaments, Z-line and M-line attachments to the sarcolemma by costameric proteins and the elastic filament protein titin (Taylor et al., 1995). Figs. 1 and 2 show histological changes of the duck breast and leg meat by TEM with magnification $(\times 10,000)$ during aging at $0^{\circ} \mathrm{C}$. In Fig. 1 , there are 4 pictures (a, b, c, and $d$ ) indicating the histological changes of meat struc-

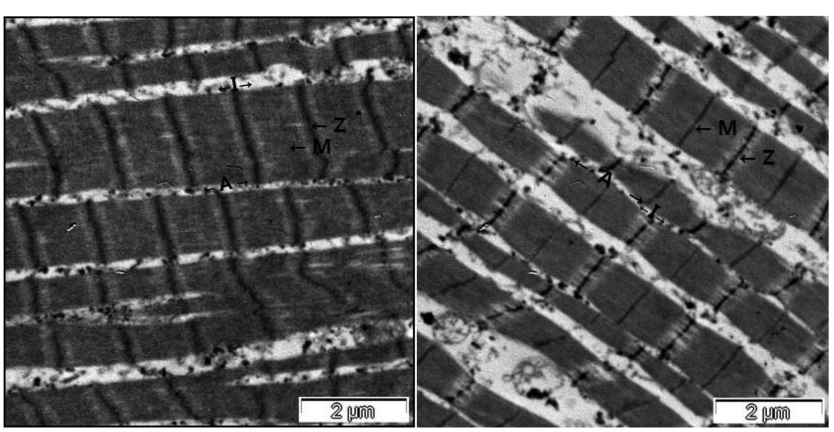

(a)

(b)

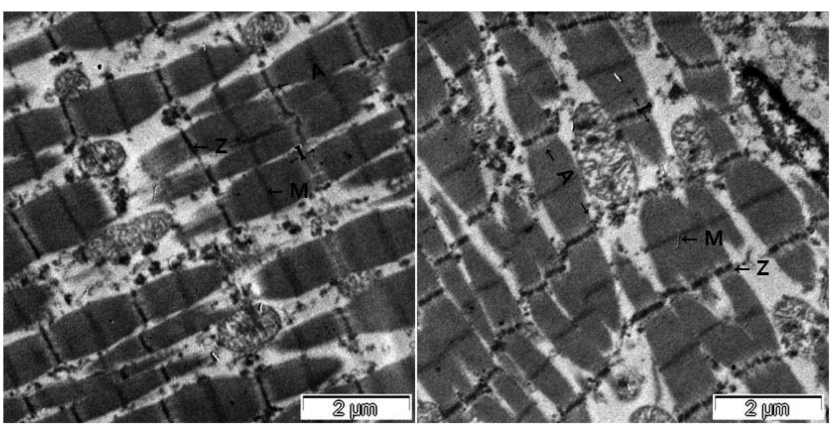

(c)

(d)

Fig. 1. Histological changes of the duck breast meat with magnification $\left(\times \mathbf{1 0 , 0 0 0 )}\right.$ during aging at $0^{\circ} \mathrm{C}$ for $7 \mathrm{~d}$. (a), day 0 ; (b), day 2; (c), day 5; (d), day 7 
ture by the period of aging. Picture (a) showes the structure of the meat before any chemical change has initiated. Sarcomeres were arranged evenly because this sample was just slaughtered and bones had not yet been removed. Picture (b) showes the results of aging after two days of storage. In this picture, the length of sarcomeres was increased and they were partially damaged. Also, the Zline, I-band, A-band and M-line were clearly shown, while the distance between myofibrils was increased. Pictures (c) and (d) show the result of aging after five days and seven days of storage, respectively. Myofibrils were more damaged over time. Myofibrils were collapsed, with substantial cuts in the Z-line, but the M-line was cut only in some parts of myofibrils. The size and number of mitochondria between myofibrils were increased as the aging period increased.

Fig. 2 shows histological changes of duck leg meats during aging at $0^{\circ} \mathrm{C}$ for $7 \mathrm{~d}$, as pictures were taken with the same condition of Fig. 1. At the early stage of aging (a) there were no gaps between the myofibrils, but after two days of aging Fig. 2 (b) the structure was significantly changed. This result was very similar to that of breast meat. After five days and seven days of aging (picture $\mathrm{c}$ and d) the mitochondria size and quantity was found to be increased between the myofibrils. Also, mitochondria and other cells were replaced in the space of destroyed myo-

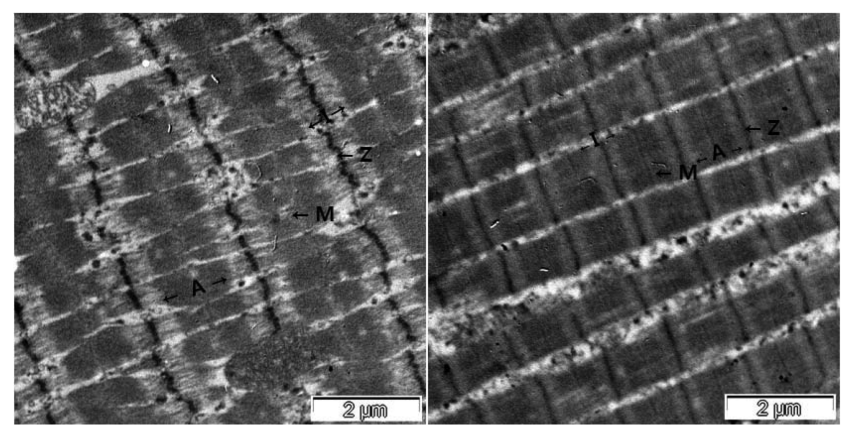

(a)

(b)

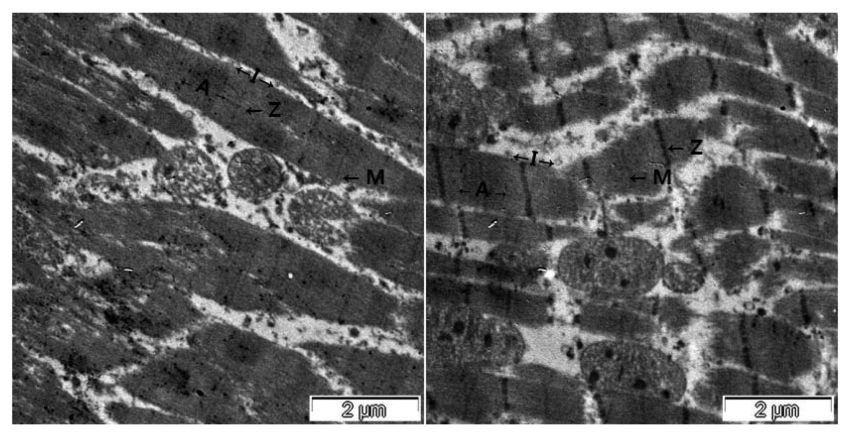

(c)

(d)

Fig. 2. Histological changes of the duck leg meat with magnification $(\times 10,000)$ during aging at $0^{\circ} \mathrm{C}$ for $7 \mathrm{~d}$. (a), day 0 ; (b), day 2; (c), day 5; (d), day 7 fibrils over time.

Gerelt et al. (2002) found that the injection of calcium chloride into beef at $3-4^{\circ} \mathrm{C}$ softened the meat. They also observed that the boundary of the M-line and I band started to destroy the $\mathrm{CaCl}_{2}$ treatment for $24 \mathrm{~h}$ compare to the control. The Z-line structure was severely damaged after $168 \mathrm{~h}$, which indicated the possibility of meat softening using the $\mathrm{CaCl}_{2}$ process. Mikel et al. (1996) also proved that the structure of beef could be changed with organic acid treatment. Taylor et al. (2002) observed histological change of moose and reindeer muscle structure after postmortem. They found out that the fiber area of the Longissmus thoracis muscle of moose was 3,270 um compared to $1,170 \mathrm{um}^{2}$ of reindeer. This resulted in that the muscle of reindeer was more tender than that of moose under the same condition. Cho et al. (1994) experimented with the histological changes of beef according to different packaging materials, like PVC-wrap and Cryo-vac, as well as determining the effect of different aging temperatures. With extended time, the structure of myofibrils changed, and the Z-line was destroyed. It was difficult to find A-band and I-band at the higher temperature. Boyer and Greaser (1998) found that beef aged at $4^{\circ} \mathrm{C}$ had a reduced Z-line. Sotelo et al. (2004) packed rabbit meat's semimembranosus muscle with petridium aquilinum and aged it for 72 hours at $4^{\circ} \mathrm{C}$, and found that parts of the perimysial, endomysial and connective tissue were damaged. After $24 \mathrm{~h}$, myofibrils' sarcolemma was reduced, spaces were widened, and tissue fiber was collapsed after $32 \mathrm{~h}$. After $72 \mathrm{~h}$, muscle bundles were reduced and intercellular spaces were widened. In conclusion, with different temperatures of storage, significant histological changes were observable after three days of aging. Irena and Anna (1995) also reported changes in the myofibrillar structure in the biceps femoris of pork by mechanical tenderizing methods.

The length of sarcomeres of muscle and meat tenderness are known to have close relationship. Goll et al.(1995) reported that the toughness of meat was decided by the strength and structure of connections between myosin and actin, which combined within $24 \mathrm{~h}$ after slaughter. There was a report that myofibril's tendency for shrinkage was affected by temperature. Also, at lower temperatures, more contraction was found in muscle (Olsson et al., 1994). Bendall (1975) also reported that muscle contraction showed more in red meat than in white meat. Also the contraction speed was different, depending on species or type of muscle. White meat has less mitochondria and better calcium binding capacity 
Table 1. Changes of sarcomere length of duck breast and leg meat by TEM during aging at $0^{\circ} \mathrm{C}$ for $7 \mathrm{~d}$ (TEM: $\times 15,750)$

\begin{tabular}{ccc}
\hline \hline \multirow{2}{*}{ Days } & \multicolumn{2}{c}{ Sarcomere length $(\mathrm{nm})$} \\
\cline { 2 - 3 } & \multicolumn{1}{c}{ Breast } & Leg \\
\hline 0 & $1,326.8 \pm 5.3^{\mathrm{d}}$ & $2,067.7 \pm 124.2^{\mathrm{a}}$ \\
1 & $1,354.6 \pm 26.6^{\mathrm{d}}$ & $1,205.8 \pm 59.9^{\mathrm{e}}$ \\
2 & $1,916.0 \pm 40.4^{\mathrm{b}}$ & $1,274.8 \pm 13.2^{\mathrm{de}}$ \\
3 & $2,062.2 \pm 34.6^{\mathrm{a}}$ & $1,381.4 \pm 29.6^{\mathrm{d}}$ \\
5 & $1,755.6 \pm 181.6^{\mathrm{c}}$ & $1,502.9 \pm 10.0^{\mathrm{c}}$ \\
7 & $1,792.5 \pm 35.1^{\mathrm{bc}}$ & $1,669.1 \pm 30.0^{\mathrm{b}}$ \\
\hline
\end{tabular}

$n=3$

${ }^{\mathrm{a}-\mathrm{e}}$ Means within a column with different letters are significantly different $(p<0.05)$.

than red meat (Cornforth et al., 1980).

Table 1 showes the changes of sarcomere lengths in duck breast and leg meat during aging at $0^{\circ} \mathrm{C}$ for $7 \mathrm{~d}$, as well as the length of space from Z-line to Z-line (sarcomere) as measured by TEM at 15,750×magnification (Figs. 3 and 4). The tendency of changes in the meat structure was the same with the result of measurement at $10,000 \times$ magnification. In this study, the change of sarcomere length was $1,326.8 \pm 5.3 \mathrm{~nm}$ in the early stage of aging. The length had increased up to $2,062.2 \pm 34.6 \mathrm{~nm}$ maximum at the aging day 3 but decreased to $1,792.5 \pm 35.1$

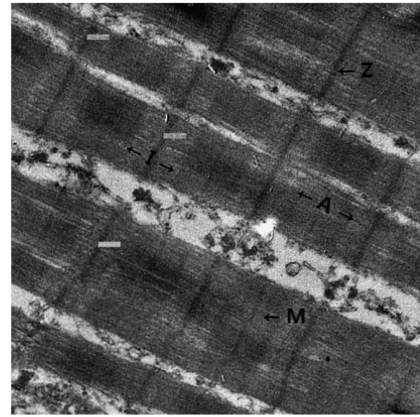

(a)

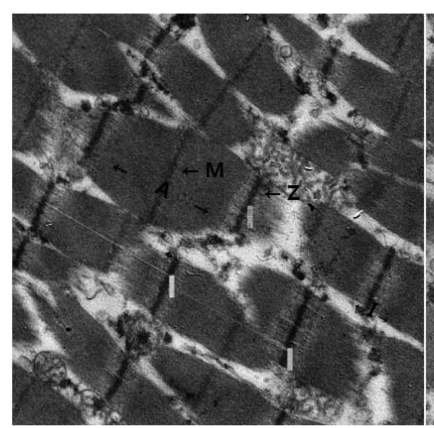

(c)

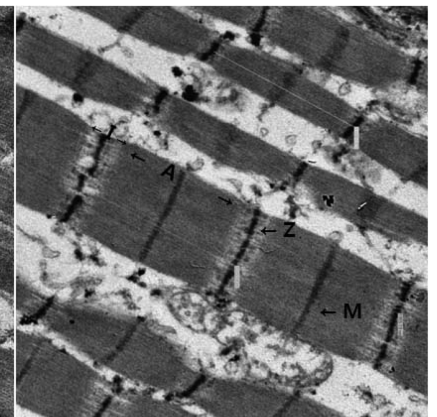

(b)

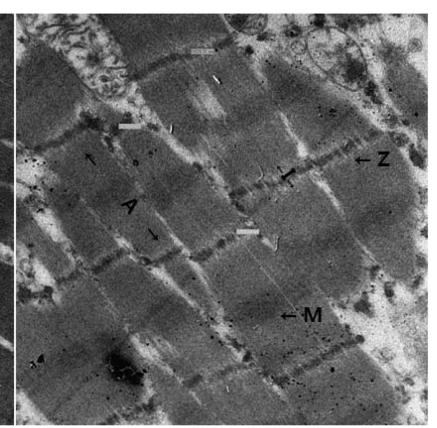

(d)
Fig. 3. Histological changes of the duck breast meat with magnification $(\times 15,750)$ during aging at $0^{\circ} \mathrm{C}$ for $7 \mathrm{~d}$ (each colored line is the length of sarcomere). (a), day 0 ; (b), day 2; (c), day 5; (d), day 7 $\mathrm{nm}$ at aging day 7. At the early stage of storage, there was no space between myofibrils, but substantial histological damage took place after five days of storage. This tendency was similar in both breast meat and leg meat. In leg meat, the length of sarcomeres was $2,067 \pm 124.2 \mathrm{~nm}$ at storage day 0 , and the length of sarcomeres of leg meat was longer than those of breast meat. However, the length of sarcomere in breast meat was longer than those of leg meat at aging day 2 . The length of sarcomeres in leg meat was reduced to $1,205.8 \pm 59.9 \mathrm{~nm}$ at aging day 2, but increased again to $1,669.1 \pm 30.0 \mathrm{~nm}$ at aging day 7 . With this result, the Z-line in the sarcomeres was cut after two to three days of aging, and most myofibrils were broken down at aging day 7. Locker (1960) reported that the contraction conditions of muscles affected the quality of meat and tastes of consumers.

Light et al. (1985) reported that tough and tender muscles had the same amount of endomysium. Furthermore, endomysium did not seem to contribute to the shear force value of single fibers (Mutungi et al., 1995). Yoon (2003) examined chicken breast meat using gamma irradiation, where chicken breast meat was aged for $14 \mathrm{~d}$ at $4^{\circ} \mathrm{C}$ to observe histological change. Yoon found that depending on irradiation, sarcomere length showed significant difference and sarcomere width was also changed. Maher et

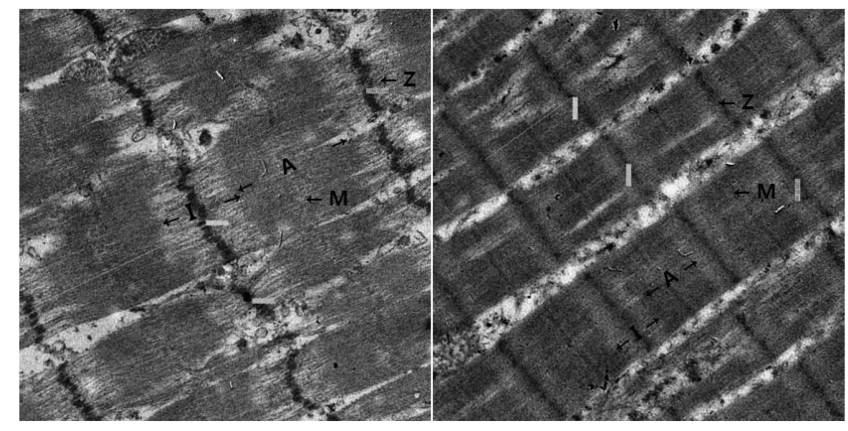

(a)

(b)

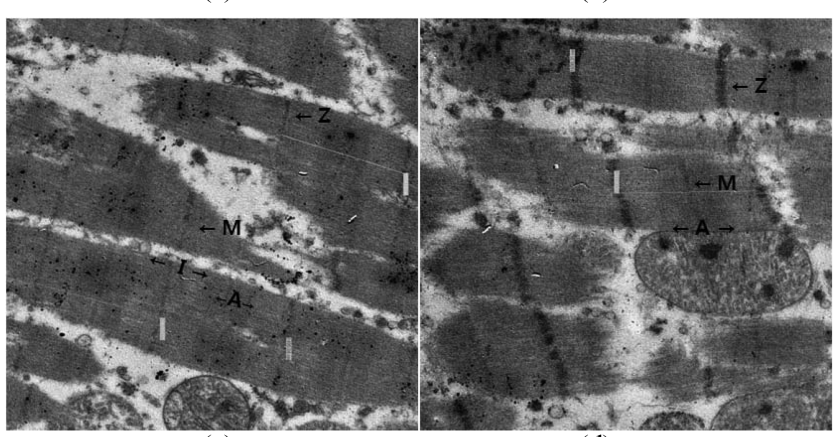

(c)

(d)

Fig. 4. Histological changes of the duck leg meat with magnification $(\times 15,750)$ during aging at $0^{\circ} \mathrm{C}$ for $7 \mathrm{~d}$ (each colored line is the length of sarcomere). (a), day 0 ; (b), day 2 ; (c), day 5 ; (d), day 7 
Table 2. Changes of shear force of duck breast meat during aging at $0^{\circ} \mathrm{C}$ for $7 \mathrm{~d}(n=7)$

\begin{tabular}{ccccccc}
\hline \hline \multirow{2}{*}{$\begin{array}{c}\text { Shear force } \\
(\mathrm{kg})\end{array}$} & 0 & 1 & 2 & 3 & 5 & 7 \\
\cline { 2 - 7 } & $10.4 \pm 1.2^{\mathrm{a}}$ & $8.6 \pm 2.3^{\mathrm{ab}}$ & $5.3 \pm 1.0^{\mathrm{b}}$ & $7.1 \pm 1.6^{\mathrm{ab}}$ & $6.9 \pm 2.3^{\mathrm{ab}}$ & $5.3 \pm 0.75^{\mathrm{b}}$ \\
\hline
\end{tabular}

${ }_{\mathrm{a}, \mathrm{b}}$ Means within a row with different letters are significantly different $(p<0.05)$.

al. (2005) tested the softness and micro histological changes in sirloin muscle of beef, and reported that the histology and softness of the meat depends on hanging duration and temperature. Actomyosin significantly contracted after two days of aging at $2^{\circ} \mathrm{C}$ with hot boning method. Carcasses sides stretched at $10^{\circ} \mathrm{C}$ for $10 \mathrm{~h}$ were tenderized and carcasses stretched for 38 hours at $2^{\circ} \mathrm{C}$ had actomyosin extended. Reports of collapsing during aging with myofibrillar fragmentation were reported by Maher et al. (2005). Moon et al. (2006) reported that the length of sarcomeres in sirloin of beef was increased significantly when aged at $0-10^{\circ} \mathrm{C}$ prior to the onset of rigor mortis.

Table 2 showes the shear force changes of duck breast meat during aging $0^{\circ} \mathrm{C}$ for $7 \mathrm{~d}$. The shear force of breast meat was $10.4 \pm 1.2 \mathrm{~kg}$ on storage day $0,8.6 \pm 2.3 \mathrm{~kg}$ on day 1 , and $5.3 \pm 0.7 \mathrm{~kg}$ on day 7 . Shear force showed a decrease during aging. This result is in agreement with the study of Yoon (2003).

\section{Acknowledgement}

This study was supported by the Korea Institute of Planning and Evaluation for Technology in Food, Agriculture, Forestry and Fisheries (\#109126-3), Ministry of Food, Agriculture and Forestry and Fisheries Korea.

\section{References}

1. Ahn, D. H. and Park, S. M. (1998) Postmortem changes in Zdisk domain of titin in the chicken muscle. Kor. J. Food Sci. An. 18, 292-300.

2. Barowicz, T. (2006) Muscle fibers and pork meat quality. Hodowca Trz. Chl. 1, 22-23.

3. Bendall, J. R. (1975) Cold-contracture and ATP-turnover in the red and white musculature of the pig, postmortem. J. Sci. Food Agric. 26, 55.

4. Boyer, B. C. and Greaser, M. L. (1998) Effects of postmortem storage on the Z-line region of titin in bovine muscle. $J$. Anim. Sci. 76, 1034-1044.

5. Cho, Y. J., Lee, N. G., Kim, Y. Y., Kim, J. H., Lee, K. W., Kim, G. B., and Choi, Y. J. (1994) Early changes after death of plaice paralichthys olivaceus muscle. Bull. Kor. Fish. Soc. 27, 327-324
6. Cornforth, D. P., Person, A. M., and Merkel, R. A. (1980) Relationship of mitochondria and sarcoplsmic reticulum to cold shortening. Meat Sci. 4, 103-121

7. Gerelt, B., Ikeuchi, Y., Nishiumi, T., and Suzuki, A. (2001) Meat tenderization by calcium chloride after osmotic dehydration. Meat Sci. 60, 237-244.

8. Gerelt, B., Ikeuchi, Y., Nishiumi, T., and Suzuki, A. (2002) Meat tenderization by calcium chloride after osmotic dehydration. Meat Sci. 60, 237-244

9. Goll, D. E., Otsuka, Y., Nagainis, P. A., Shannon, J. D., Sathe, S. K., and Muguruma, M. (1983) Role of muscle proteinases in maintenance of muscle integrity and mass. $J$. Food Biochem. 7, 137-177.

10. Goll, D. E., Taylor, R. G., Christiansen, J. A., and Thompson, V. F. (1992) Role of proteinases and protein turnover in muscle growth and meat quality. Proc. Recip. Meat Conf. 44, 2536.

11. Goll, D. E., Geesink, G. H., Taylor, R. G., and Thompson, V. F. (1995) Does proteolysis cause all postmortem tenderization, or are changes in the actin/myosin interaction involved? Proc. Int. Cong. Meat Sci. Technol. 41, 537-544

12. Illian, M. A., Alaa, E. D. A B., Stevenson, B., Morton, J. D., Isherwood, P., and Bickerstaffe, R. (2004) Up and down regulation of longissimus tenderness parallels changes in the myofibril-bound calpain 3 protein. Meat Sci. 67, 433-445.

13. Irena, T. and Anna, J. P. (1995) Ultrastructure of mechanically tenderized pork muscle. Meat Sci. 41, 273-282

14. Koohmaraie, M. (1995) The biological basis of meat tenderness and potential genetic approaches for its control and prediction. Proc. Recip. Meat Conf. 48, 69-75.

15. Koohmaraie, M. (1996) Biochemical factors regulating the toughening and tenderization processes of meat. Meat Sci. 43, S193-S201.

16. Koohmaraie, M., Shackelford, S. D. Wheeler, T. L. Lonergan, S. M., and Doumit, M. E. (1995) A muscle hypertrophy condition in lamb (callipyge): Characterization of effects on muscle growth and meat quality traits. J. Anim. Sci. 73, 3596-3607.

17. Lee, Y. B., Hargus, G. L., Webb, J. E., Rickansrud, D. A., and Hagberg, E. C. (1979) Effect of electrical stimulation on postmortem biochemical changes and tenderness in broiler breast muscle. J. Food Sci. 44, 1121-1122.

18. Light, N., Champion, A. E., Voyle, C., and Bailey, A. J. (1985) The role of epimysial and endomysial collagen in determining texture in six bovine muscles. Meat Sci. 13, 137149.

19. Locker, R. H. (1960) Degree of muscular contraction as a factor in tenderness of beef. Food Res. 25, 304-307. 
20. Maher, S. C., Mullen, A. M., and Mononey, A. P. (2005) Ultrastructural variation in beef $M$. longissimus dorsi as an explanation of the variation in beef tenderness. J. Food Sci. 70, 579-584.

21. Mestre Prates, J. A., Garcia e Costa, F. J. S., Ribeiro, A. M. R., and Dias Correia, A. A. (2002) Contribution of major structural changes in myofibrils to rabbit meat tenderisation during ageing. Meat Sci. 61, 103-113.

22. Mikel, W.B., Goddard, B.L., and Bradford, D. D. (1996) Muscle microstructure and sensory attributes of organic acid treated beef strip loins. J. Food Sci. 61, 1058-1062.

23. Moon, S. S., Yang, H. S., Park, G. B., and Joo, S. T. (2006) The effects of stretching and temperature of pre-rigor $M$. longissimus on sarcomere length and tenderness of beef. Kor. J. Food Sci. An. 26, 189-196.

24. Mutungi, G., Purslow, P., and Warkup, C. (1995) Structural and mechanical changes in raw and cooked single porcine muscle fibers extended to fracture. Meat Sci. 40, 217-234.

25. Olsson, U., Hertzman. C., and Tornberg, E. (1994) The influence of low temperature, type of muscle and electrical stimulation on the course of rigor, ageing and tenderness of beef muscles. Meat Sci. 37, 115-131.

26. Ouali, A. (1992) Proteolytic and physicochemical mechanisms involved in meat texture development. Biochimie 74, 251-265
27. Robson, R. M., Huff-Lonergan, E., Parrish, F. C., Ho, C. Y., Stromer, M. H., and Huiatt, T. W. (1997) Postmortem changes in the myofibrillar and cytoskeletal proteins in muscle. Proc. Recip. Meat Conf. 43-52.

28. SAS (2002) SAS/STAT Software for PC. SAS Institute, Inc., Cary, NC, USA.

29. Sotelo, I., Perez-Munuera, I., Quiles, A., Hernando, I., Larrea, V., and Lluch, M. A. (2004) Microstructural changes in rabbit meat wrapped with Pteridium aquilinum fern during postmortem storage. Meat Sci. 66, 823-829.

30. Suzuki, A., Matsumoto, Y., Sato, T., and Nonami, Y. (1982) $\mathrm{Ca}^{+-}$activated protease in stored muscle. Meat Sci. 7, 269278.

31. Taylor, R. G., Geesink, G. H., Thompson, V. F., Koohmaraie, M., and Goll, D. E. (1995) Is Z-disk degradation responsible for postmortem tenderization? J. Anim. Sci. 21, 1351-1367.

32. Taylor R. G., Labas, R., Smulders, F. J. M., and Wiklund, E. (2002) Ultrastructural changes during aging in M. longissimus thoracis from moose and reindeer. Meat Sci. 60, 321326.

33. Yoon, K. S. (2003) Effects of gamma irradiation on the texture and microstructure of chicken breast meat. Meat Sci. 63, 273-277.

(Received 2012.2.9/Revised 2012.6.3/Accepted 2012.9.4) 